\title{
Carica Papaya Mouthwash for Reducing Dental Plaque
}

\author{
Méndez J, DDs, Msc ${ }^{1,2^{*}}$ and Villasanti U, DDs, Msc ${ }^{2}$ \\ ${ }^{1}$ Instituto Regional de Investigación en Salud, Universidad Nacional de Caaguazú, Paraguay \\ ${ }^{2}$ Facultad de Odontología, Universidad Nacional de Caaguazú, Paraguay
}

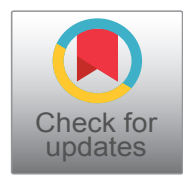

*Corresponding author: Julieta Méndez, Instituto Regional de Investigación en Salud, Universidad Nacional de Caaguazú, Dirección: Tuyuti y Mariscal Estigarribia, Coronel Oviedo, Paraguay, Tel: +595-985-300-046

\begin{abstract}
Paraguay is a country that uses a lot of herbal products containing plants as active ingredients. The use of herbs is popular mainly to the reason that is safe and easy available. In the case of the mouthwash which is a complement to brushing, the use of Carica papaya has been studied.
\end{abstract}

\section{Keywords}

Papaya, Mouthwash, Herbs

Nowadays the trend is to use natural health products due the quest for suitable and affordable alternatives. This is especially common in Paraguay, which is a country that uses a lot of herbal products containing plants as active ingredients. Herbs are being widely explored to discover alternatives to synthetic antibacterial agents as they are easy available, cost effectiveness and don't have any side effects.

Carica papaya is widely cultivated in tropical and subtropical countries and is used as food as well as traditional medicine to treat a range of diseases [1]. Carica papaya seeds contain chemical compounds such as saponin, tannin, alkaloid and flavonoid which are able to exhibit anti-inflammatory and antibacterial activity [2]. The use of Carica papaya as a mouthwash has been studied.

A clinical trial concluded that the Carica papaya leaf extract dentifrice is effective in the reduction of gingival bleeding and inflammation [3]. The findings in this study indicate that Carica papaya mouthwash used alone is safe, as mentioned in an in vitro study [4], but does not inherently mean the absence of any adverse outcomes.
Another clinical trial concluded that an herbal mouthwash of dried seeds of C. papaya as an adjunct to scaling provides more favorable approach in the treatment of plaque-induced gingivitis, periodontitis and also oral malodor [5]. This study remarks that the proportionate high amount of tannins in the seeds of $C$. papaya explains its strong antimicrobial activity.

Other clinical trial study showed that rinsing with $10 \%$ Carica papaya L. seeds extract mouthwash ware able to reduce dental plaque score in patients with gingivitis [2]. In the case of $2.5 \%$ papaya leaf extract solution, the effect in decreasing plaque index and gingival index in moderate gingivitis is the same of $0.2 \%$ chlorhexidine according to a study [6].

The limitations of these studies were the small sample and short follow-up. So further research needs to be done on a long time and bigger samples.

\section{References}

1. Nguyen TTT, Shaw PN, Parat MO, Hewavitharana AK (2013) Anticancer activity of carica papaya: A review. Mol Nutr Food Res 57: 153-164.

2. Rohman N, Suryono SH, Al Sri Koes Soesilowati SU (2016) Pengaruh berkumur dengan larutan ekstrak biji pepaya (carica papaya I.) 10\% terhadap skor plak gigi pada penderita gingivitis.

3. Saliasi I, Llodra JC, Bravo M, Tramini P, Dussart C, et al. (2018) Effect of a toothpaste/mouthwash containing carica papaya leaf extract on interdental gingival bleeding: A randomized controlled trial. Int J Environ Res Public Health 15: 2660 .

4. Bhayya DP, Singh M, Dadarya S, Kumar P, Tiwari S, et al. (2019) To evaluate and compare the antibacterial activity of freshly prepared punicagranatum, syzygiumcumini extract 
mouthwash \& a combination of carica papaya with ananascomosus in contrast with chlorhexidene against streptococcus mutans. Univ J Dent Sci 5: 36-39.

5. Rangaraju VM, Mousin S, Babu HM, Dasappa S (2019) Efficacy of carica papaya seed extract on periodontitis: A clinico-microbiological study. Int J Oral Care Res 7: 35.
6. Ardyanti R, Regina TC Tandelilin, Alma L, Jonarta MK (2017) Pengaruh berkumur ekstrak daun pepaya (carica papaya I.) 2,5\% terhadap akumulasi plak dan status gingiva pada penderita gingivitis kategori sedang. 